\title{
The morphology, porosity and productivity control of carbon nanofibers or nanotubes on modified activated carbon
}

\author{
Xiao-Wei Chen ${ }^{\mathbf{a}}$, Dang Sheng $\mathrm{Su}^{\mathbf{a}, *}$, Sharifah B.A. Hamid ${ }^{\mathbf{b}}$ and Robert Schlögl ${ }^{\mathbf{a}}$ \\ ${ }^{a}$ Fritz-Haber Institute of the Max Planck Society, Faradayweg 4-6, D-14195 Berlin, Germany \\ ${ }^{\mathrm{b}}$ Combinatorial Technology and Catalysis Research Center, Universiti Malaya, 50603 Kuala Lumpur, \\ Malaysia \\ *Corresponding author. Tel.: +49 30 84135406; fax: +49 30 84134401; email: dangsheng@fhi-berlin.mpg.de
}

Since their discovery, carbon nanotubes and carbon nanofibers (CNTs or CNFs) have exhibited potential in a wide range of physical and chemical applications [1] and [2]. For applications in gas phase catalysis, loose CNTs or CNFs are unsuited because they limit the catalyst-reactant transport properties and they are difficult to handle when filling in the reactor tubes. In addition, there is a health risk associated with loose CNTs or CNFs [3]. Immobilizing CNTs or CNFs on a supporting material is thus highly desirable. CNFs or CNTs have previously been grown on carbon materials, particularly on CNT or CNF support [4], [5], [6] and [7]. Activated carbon (AC) has been widely used as an efficient adsorbent for the purification of water, air and many fluid synthetic and natural products [8]. Previously we have reported that CNFs nested inside and immobilized onto modified AC exhibit an excellent adsorption behavior for heteropolymolybdate compared to metal cations [9]. The productivity of CNFs and CNTs is a function of the preparation conditions, such as nature of the substrate and of the catalyst, temperature, gas composition and time on stream [10] and [11]. In this work, a systematic study was conducted of the parameters for the synthesis of CNFs from $\mathrm{C}_{2} \mathrm{H}_{4}$ on modified AC. The productivity, porosity and morphology of the CNF/AC composites can be controlled with iron salt precursors, the ratio of $\mathrm{C}_{2} \mathrm{H}_{4} / \mathrm{H}_{2}$, the reaction temperature and the reaction time.

The preparation procedures of $\mathrm{Fe} / \mathrm{AC}$ catalysts and $\mathrm{CNF} / \mathrm{AC}$ composites have been described in our previous work [9]. Before impregnation, the $\mathrm{AC}$ was calcined at $400{ }^{\circ} \mathrm{C}$ for $4 \mathrm{~h}$ in air. The $\mathrm{pH}$ values of iron nitrate, iron acetate and iron citrate aqueous solutions were adjusted to 2.0 with $\mathrm{NH}_{3} \cdot \mathrm{H}_{2} \mathrm{O}$ aqueous solution or concentrated acetic acid respectively. The $1 \mathrm{wt} \% \mathrm{Fe} / \mathrm{AC}$ catalysts were prepared by incipient wetness impregnation using $0.09 \mathrm{M}$ aqueous solutions of iron citrate, iron acetate and iron nitrate $\left(2.0 \mathrm{~cm}^{3}\right)$ and modified AC $(1 \mathrm{~g})$. During the CNF or CNT growth, the temperature was varied between 500 and $800{ }^{\circ} \mathrm{C}$, while reaction time was varied from 10 to $120 \mathrm{~min}$.

The elemental analysis shows that the carbon, hydrogen, nitrogen and oxygen in the raw $\mathrm{AC}$ are 92.42, 0.46, 0.35 and $0.82 \mathrm{wt} \%$. The total content of $\mathrm{Fe}$ and $\mathrm{Ca}$ is about $2.91 \%$. The rest components are silicon, potassium, and other impurities. A blank experiment was also performed on the modified AC. After reaction of a mixture of ethylene and $\mathrm{H}_{2}$ at $700{ }^{\circ} \mathrm{C}$ for $2 \mathrm{~h}$, the weight of $\mathrm{AC}$ increases from 100 to $130 \mathrm{mg}$ indicating that carbon deposits on the AC. Scanning electron microscopy (SEM) confirms that carbon is deposited in the form of CNFs with diameters in the range from 20 to $500 \mathrm{~nm}$.

The iron particles prepared with iron nitrate are the largest with the particle size distribution from 20 to $200 \mathrm{~nm}$. The average size of iron particles obtained using iron acetate is about $20 \mathrm{~nm}$. Iron particles are not readily found when using iron citrate as precursor. However, iron can be detected by energy dispersive X-ray analysis, indicating that iron is well-dispersed on the surface of the AC. The difference in iron particle sizes of the Fe/AC catalysts leads to different diameters of CNFs on AC. The order of CNF diameters prepared with different iron precursors is: iron 
nitrate $>$ iron acetate $>$ iron citrate (Fig. 1). Similar to our previous work [9], CNFs can be observed not only on the surface but also in the pores of AC.

A

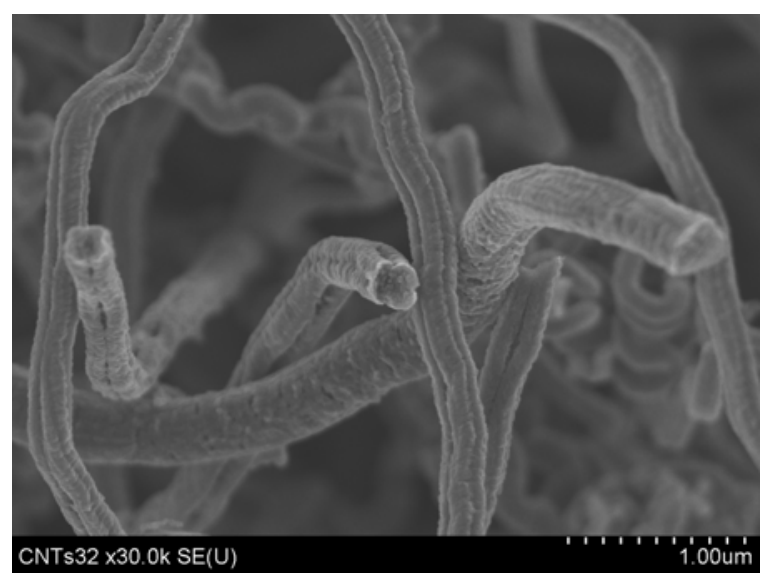

B

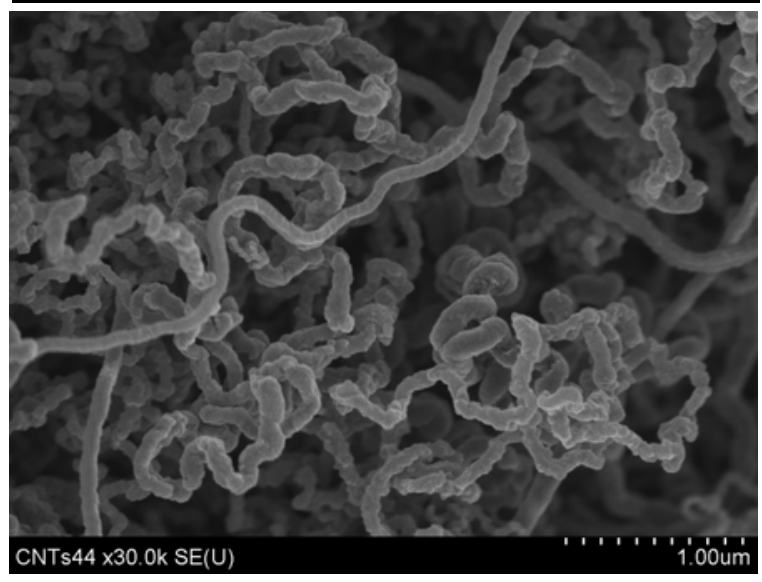

C

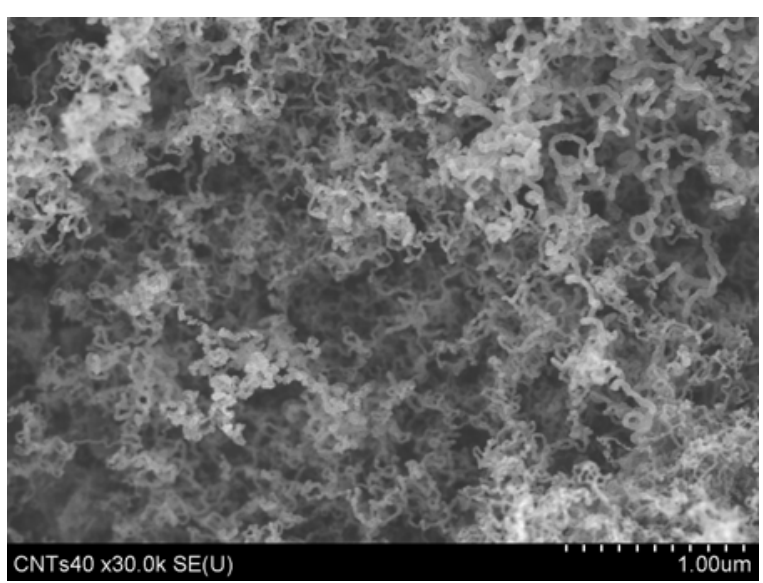

Figure 1. $\mathrm{CNF} / \mathrm{AC}$ composites prepared with different iron precursors: $(\mathrm{A})$ iron nitrate, $(\mathrm{B})$ iron acetate and $(\mathrm{C})$ iron citrate. Scale bar: $1 \mu \mathrm{m}$.

Table 1 summarizes the productivities, BET surface areas, pore volumes and diameter distributions of $\mathrm{CNF} / \mathrm{AC}$ composites as a function of iron precursors. The $\mathrm{Fe} / \mathrm{AC}$ catalyst prepared with iron nitrate gives the highest productivity of CNFs on $\mathrm{AC}(107.6 \mathrm{~g} \mathrm{C} / \mathrm{g} \mathrm{Fe})$, whereas the productivity of catalysts prepared with iron citrate and iron acetate is 62.5 and 53.3 $\mathrm{g} \mathrm{C} / \mathrm{g} \mathrm{Fe}$, respectively. The BET specific surface areas of the CNF/AC composites decrease from 1237 to less than $100 \mathrm{~m}^{2} / \mathrm{g}$. Meanwhile, the total pore volume decreases from 0.547 to around $0.08 \mathrm{~cm}^{3} / \mathrm{g}$. The dramatic decreases of BET specific surface area and pore volume for CNF/AC composites are attributed to the decrease of micropores of CNF/AC composites. The Fe/AC catalyst prepared with iron nitrate produces the biggest diameters of CNFs and the highest productivity of CNFs on AC. In the following experiments, iron nitrate was chosen as the iron precursor. 
Table 1 Productivities, BET surface areas, pore volumes and diameter distributions of CNF/AC composites as a function of iron precursor. Synthesis conditions: $1 \mathrm{wt} \% \mathrm{Fe} / \mathrm{AC}$ catalyst, $\mathrm{C}_{2} \mathrm{H}_{4}: \mathrm{H}_{2}=50: 50$ $\mathrm{cm}^{3} / \mathrm{min}, 700{ }^{\circ} \mathrm{C}$ for $2 \mathrm{~h}$.

\begin{tabular}{cccccccc}
\hline Samples & $\begin{array}{c}\text { Fe } \\
\text { precursor }\end{array}$ & $\begin{array}{c}\text { Productivity } \\
(\mathrm{g} \mathrm{C} / \mathrm{g} \mathrm{Fe})\end{array}$ & $\begin{array}{c}\text { BET } \\
\text { surface } \\
\text { area } \\
\left(\mathrm{m}^{2} / \mathrm{g}\right)\end{array}$ & $\begin{array}{c}\text { Total } \\
\text { pore }\end{array}$ & $\begin{array}{c}\text { Molume } \\
\left(\mathrm{cm}^{3} / \mathrm{g}\right)\end{array}$ & $\begin{array}{c}\text { Micropore } \\
\text { volume }\end{array}$ & \multicolumn{2}{c}{ Diameter distribution } \\
\cline { 6 - 7 } & & & 1081 & 0.365 & - & \\
\hline $\mathrm{cm} / \mathrm{g})$ & $\begin{array}{c}\text { Diameter } \\
\text { range }(\mathrm{nm})\end{array}$ & $\begin{array}{c}\text { Dominant } \\
\text { diameter }(\mathrm{nm})\end{array}$ \\
$\mathrm{AC}-400$ & & & 1237 & 0.547 & 0.514 & & \\
CNTs-40 & Fe citrate & 62.5 & 17.7 & 0.009 & 0.029 & $20-100$ & 20 \\
CNTs-44 & Fe acetate & 53.3 & 91.5 & 0.078 & 0.048 & $50-200$ & 100 \\
CNTs-32 & Fe nitrate & 107.6 & 56.0 & 0.080 & 0.038 & $50-400$ & 200 \\
\hline
\end{tabular}

The ratio of hydrocarbon to hydrogen is essential for the CNT or CNF growth [10] and [11]. $\mathrm{H}_{2}$ might have an impact on both the morphology and productivity of CNTs or CNFs. The total flow rate of the $\mathrm{C}_{2} \mathrm{H}_{4}$ and $\mathrm{H}_{2}$ mixture is $100 \mathrm{~cm}^{3} / \mathrm{min}$. When only $\mathrm{H}_{2}$ was introduced into the $\mathrm{Fe} / \mathrm{AC}$ catalyst bed, no CNFs were produced and only Fe particle was observed. When the ratio of $\mathrm{C}_{2} \mathrm{H}_{4}$ to $\mathrm{H}_{2}$ was $2: 8, \mathrm{CNFs}$ were observed on the surface of the Fe/AC catalyst. The diameters of most CNFs were between 150 to $1000 \mathrm{~nm}$. The diameters of CNFs are more uniform and less than 300 $\mathrm{nm}$ when the $\mathrm{C}_{2} \mathrm{H}_{4}: \mathrm{H}_{2}$ ratio is 5:5. The diameters of CNFs become smaller with increasing $\mathrm{C}_{2} \mathrm{H}_{4} / \mathrm{H}_{2}$ ratio. The diameters of CNFs prepared with pure $\mathrm{C}_{2} \mathrm{H}_{4}$ are less than $100 \mathrm{~nm}$. HRTEM images confirm that graphite layer of a CNT formed when only $\mathrm{C}_{2} \mathrm{H}_{4}$ was introduced into the $\mathrm{Fe} / \mathrm{AC}$ catalyst bed. The productivities of CNFs are 0, 70, 107.6, $62.5 \mathrm{and} 53 \mathrm{~g} \mathrm{C} / \mathrm{g}$ Fe when the $\mathrm{C}_{2} \mathrm{H}_{4} / \mathrm{H}_{2}$ ratios are 0:1, 2:8, 5:5, 8:2 and 1:0 respectively. Higher $\mathrm{H}_{2}$ concentration helps remove the carbon layer, which might then enhance the carbon formation. However, the higher ratio of $\mathrm{C}_{2} \mathrm{H}_{4}$ to $\mathrm{H}_{2}$ does not lead to higher productivity of CNFs since $\mathrm{H}_{2}$ is also generated from ethylene decomposition. The maximum growth of CNFs is achieved at a $\mathrm{C}_{2} \mathrm{H}_{4} / \mathrm{H}_{2}$ ratio around 5:5 under the tested conditions. Similar results have been shown by Baker [10].

Table 2 Productivities, BET surface areas, pore volumes and diameter distributions of CNF/AC composites as a function of temperature. Synthesis conditions: $1 \mathrm{wt} \% \mathrm{Fe} / \mathrm{AC}$ catalyst (iron nitrate precursor), $\mathrm{C}_{2} \mathrm{H}_{4}: \mathrm{H}_{2}=50: 50 \mathrm{~cm}^{3} / \mathrm{min}, 2 \mathrm{~h}$.

\begin{tabular}{|c|c|c|c|c|c|c|c|}
\hline \multirow[t]{2}{*}{ Samples } & \multirow{2}{*}{$\begin{array}{c}\text { Reaction } \\
\text { temperature }\left({ }^{\circ}\right. \\
\text { C) }\end{array}$} & \multirow{2}{*}{$\begin{array}{l}\text { Productivity } \\
\qquad(\mathrm{g} \mathrm{C} / \mathrm{g} \mathrm{Fe})\end{array}$} & \multirow{2}{*}{$\begin{array}{l}\text { BET } \\
\text { surface } \\
\text { area } \\
\left(\mathrm{m}^{2} / \mathrm{g}\right)\end{array}$} & \multirow{2}{*}{$\begin{array}{c}\text { Total } \\
\text { pore } \\
\text { volume } \\
\left(\mathrm{cm}^{3} / \mathrm{g}\right)\end{array}$} & \multirow{2}{*}{$\begin{array}{l}\text { Micropore } \\
\text { volume } \\
\left(\mathrm{cm}^{3} / \mathrm{g}\right)\end{array}$} & \multicolumn{2}{|c|}{ Diameter distribution } \\
\hline & & & & & & $\begin{array}{l}\text { Diameter } \\
\text { range }(\mathrm{nm})\end{array}$ & $\begin{array}{c}\text { Dominant } \\
\text { diameter }(\mathrm{nm})\end{array}$ \\
\hline CNTs-34 & 500 & 19.1 & 1121 & 0.600 & 0.499 & $40-120$ & 40 \\
\hline CNTs-33 & 600 & 61.3 & 742.5 & 0.432 & 0.347 & $50-400$ & 200 \\
\hline CNTs-32 & 700 & 107.6 & 56.0 & 0.080 & 0.038 & $50-400$ & 200 \\
\hline CNTs-35 & 800 & 93.5 & 38.5 & 0.011 & 0.026 & $50-400$ & 200 \\
\hline
\end{tabular}


The reaction temperature also plays an important role in CNF growth. Short CNFs or carbon nanospheres with nano-sized Fe particles were obtained at $500{ }^{\circ} \mathrm{C}$. The length of CNFs increases from $600 \mathrm{~nm}$ to $2 \mu \mathrm{m}$ when the temperature is increased from 500 to $600^{\circ} \mathrm{C}$. The length of the CNFs is up to $20 \mu \mathrm{m}$ and the surface of the CNFs is less defective when the reaction temperature is $700{ }^{\circ} \mathrm{C}$. The CNFs prepared at $800 \mathrm{C}$ do not show the characteristic round nanofibers synthesized at lower temperatures, instead of the curved fibers. As seen in Table 2, the maximum productivity was obtained at a growth temperature of $700 \mathrm{C}$ where also the least defective CNFs were obtained. The dependence of CNF productivity on the reaction temperature can be described as follows: First, the conversion of ethylene increases with increasing temperatures, i.e., more carbon will be deposited on the Fe/AC catalyst. This explains why the CNFs become longer at higher temperatures. Second, the carbon solubility and diffusion will be higher at higher temperatures. Therefore carbon diffusion through the metal particles is faster, benefiting catalyst activation and CNF growth. The BET surface areas and the total pore volumes decrease with increasing reaction temperature. This can be partly attributed to the fact that the CNFs are immobilized not only on the surface but also in the pores of the AC.

Table 3 Productivities, BET surface areas, pore volumes and diameter distributions of CNF/AC composites as a function of reaction time. Synthesis conditions: $1 \mathrm{wt} \% \mathrm{Fe} / \mathrm{AC}$ catalyst (iron nitrate precursor), $\mathrm{C}_{2} \mathrm{H}_{4}: \mathrm{H}_{2}=50: 50 \mathrm{~cm}^{3} / \mathrm{min}$, at $700{ }^{\circ} \mathrm{C}$.

\begin{tabular}{|c|c|c|c|c|c|c|c|}
\hline \multirow[t]{2}{*}{ Samples } & \multirow{2}{*}{$\begin{array}{l}\text { Reaction } \\
\text { time } \\
\text { (min) }\end{array}$} & \multirow{2}{*}{$\begin{array}{l}\text { Productivity } \\
\text { (g C/g Fe) }\end{array}$} & \multirow{2}{*}{$\begin{array}{c}\text { BET } \\
\text { surface } \\
\text { area } \\
\left(\mathrm{m}^{2} / \mathrm{g}\right)\end{array}$} & \multirow{2}{*}{$\begin{array}{c}\text { Total pore } \\
\text { volume } \\
\left(\mathrm{cm}^{3} / \mathrm{g}\right)\end{array}$} & \multirow{2}{*}{$\begin{array}{l}\text { Micropore } \\
\text { volume } \\
\left(\mathrm{cm}^{3} / \mathrm{g}\right)\end{array}$} & \multicolumn{2}{|c|}{ Diameter distribution } \\
\hline & & & & & & $\begin{array}{l}\text { Diameter } \\
\text { range (nm) }\end{array}$ & $\begin{array}{c}\text { Dominant } \\
\text { diameter }(\mathrm{nm})\end{array}$ \\
\hline CNTs-27 & 10 & 24.4 & 1013 & 0.575 & 0.467 & $50-250$ & 50 \\
\hline CNTs-26 & 30 & 45.0 & 727.0 & 0.488 & 0.356 & $50-400$ & 200 \\
\hline CNTs-20 & 60 & 84.7 & 184.2 & 0.157 & 0.102 & $50-400$ & 200 \\
\hline CNTs-32 & 120 & 107.6 & 56.0 & 0.080 & 0.038 & $50-400$ & 200 \\
\hline
\end{tabular}

Table 3 lists the productivities, BET surface areas, pore volumes and diameter distribution of $\mathrm{CNF} / \mathrm{AC}$ composites as a function of reaction time. The reaction time was varied between 10 and $120 \mathrm{~min}$. The longest CNFs are up to $3 \mu \mathrm{m}$ when the reaction time is $10 \mathrm{~min}$. When increasing the reaction time to $30 \mathrm{~min}$, the length of the CNFs is up to $7 \mu \mathrm{m}$. Meanwhile, the productivity increases from 24.4 to $45.0 \mathrm{~g} \mathrm{C} / \mathrm{g}$ Fe. Tripling the reaction time does not lead to a tripling of the productivity, meaning that the growth rate of CNFs is quite fast in the first $10 \mathrm{~min}$, and then decreases. When the reaction time is $60 \mathrm{~min}$, longer CNFs and higher CNF productivity were obtained. However, the diameters of the CNFs do not change. The same thing occurs when the reaction time is increased to $120 \mathrm{~min}$. The length of CNFs becomes longer and the productivity of CNFs increases with increasing reaction time. The decreased growth rate could be attributed to a catalyst deactivation process. The initial decomposition of ethylene is to provide nucleation sites for the growth of CNFs. This is why the iron particles can be easily observed when reaction time is less than $30 \mathrm{~min}$. Similarly, an increase of deposited carbon productivity was reported by Venegoni et al. during the first $60 \mathrm{~min}$ and a stable productivity is observed after $60 \mathrm{~min}$ [11]. After immobilization of CNFs on $\mathrm{AC}$, the percentage of micropore volume in the total pore volume decrease with increasing reaction time. The micropore volume and BET surface area decrease with increasing reaction time. The immobilization of CNFs on $\mathrm{AC}$ with different reaction times has a significant influence on morphology of CNFs, the porosity and surface area of AC. 
In conclusion, the chemical vapor deposition synthesis conditions of CNFs/AC composites have been investigated. The Fe/AC catalyst prepared with iron nitrate produces the highest productivity of $\mathrm{CNF} / \mathrm{AC}$ composites, whereas the catalysts prepared using iron citrate and iron acetate lead to CNFs with smaller diameters. The highest productivity was obtained with a $\mathrm{C}_{2} \mathrm{H}_{4}: \mathrm{H}_{2}$ ratio of 5:5. The reaction temperature determines the morphology and productivity of $\mathrm{CNF} / \mathrm{AC}$ composites. The productivity of $\mathrm{CNF} / \mathrm{AC}$ increases with reaction time, but not linearly and the $\mathrm{CNF}$ growth rate decreases with reaction time.

\section{References:}

[1] Terrones M. Science and technology of the twenty-first century: synthesis, properties, and applications of carbon nanotubes. Annu Rev Mater Res 2003;33:419-501.

[2] Serp P, Corrias M, Kalck P. Carbon nanotubes and nanofibers in catalysis. Appl Catal A 2003;253:337-58.

[3] Warheit DB. What is currently known about the health risks related to carbon nanotube exposures? Carbon 2006;44:1064-9.

[4] Otsuka K, Abe Y, Kanai N, Kobayashi Y, Takenaka S, Tanabe E. Synthesis of carbon nanotubes on Ni/carbon-fiber catalysts under mild conditions. Carbon 2004;42:727-36.

[5] Pham-Huu C, Keller N, Roddatis VV, Mestl G, Schlögl R, Leoux MJ. Large scale synthesis of carbon nanofibers by catalytic decomposition of ethane on nickel nanclusters decorating carbon nanotubes. Phys Chem Chem Phys 2002;4:514-21.

[6] Hou H, Reneker DH. Carbon nanotubes on carbon nanofibers: a novel structure based on electrospum ploymer nanofibers. Adv Mater 2004;16:69-73.

[7] Delgado JJ, Vieira R, Rebmann G, Su DS, Keller N, Ledoux MJ, et al. Supported carbon nanofibers for the fixed-bed synthesis of styrene. Carbon 2006;44:809-11.

[8] Pelekani C, Snoeyink VL. Competitive adsorption between atrazine and methylene blue on activated carbon: the importance of pore size distribution. Carbon 2000;38:1423-36.

[9] Su DS, Chen X, Weinberg G, Klein-Hoffman A, Timpe O, Hamid SBA, et al. Hierarchically structured carbon: synthesis of carbon nanofibers nested inside or immobilized onto modified activated carbon. Angew Chem Int Ed 2005;44:5488-92.

[10] Park C, Baker RTK. Carbon deposition on iron-nickel during interaction with ethylene-carbon monoxide-hydrogen mixtures. J Catal 2000;190:104-17.

[11] Venegoni D, Serp P, Feurer R, Kihn Y, Vahlas C, Kalck P. Parametric study for the growth of carbon nanotubes by catalytic chemical vapor deposition in a fluidized bed reactor. Carbon 2002;40:1799-807. 